\title{
KOSAKATA PADA KEMASAN DAN TEKNIK PENERJEMAHANNYA KE DALAM BAHASA ARAB
}

\author{
Regi Fajar Subhan ${ }^{1,2}$ \\ ${ }^{1}$ Fakultas Ilmu Budaya Universitas Padjadjaran \\ ${ }^{2}$ Email: regifsubhan28@gmail.com
}

\begin{abstract}
This paper analyzes various techniques of translation which is used in the text on the package of several snack products that is produced in Indonesia. The most important thing to be known by consumer from the snack package is its expiration date and the composition of the product. This study discusses the translation techniques used from Indonesian into Arabic. Based on these problems, study aims to find out the techniques which is used by translator according to the theory of Molina and Albir (2002) which proposed 18 different techniques. The method for this research is qualitative descriptive. The result, there are 11 kinds of techniques. Among them are as follows: amplification, borrowing, literal translation, decription, particularization, modulation, transposition, linguistic compression, calque, generalization, reduction. In addition to changing the structure, the vocabulary of the packaging text also changes in meaning.
\end{abstract}

Keywords: Translation Technique, Indonesian, Arabic, Product

$$
\begin{aligned}
& \text { ملخص } \\
& \text { تتناول هذه المقالة العلمية تقنيات الترجمة المختلفة المستخدمة في ترجمة النصوص الموجودة في علب منتجات } \\
& \text { الوجبات الخفيفة المصنوعة في إندونيسيا. أهم شيئ يجب على المستهلك معرفته في علب الوجبات الخفيفة هو }
\end{aligned}
$$

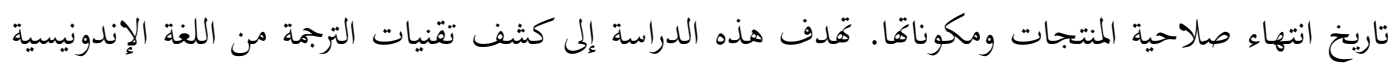

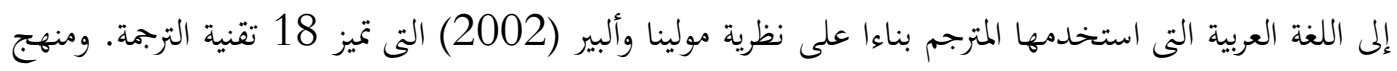

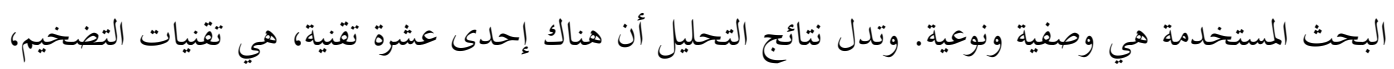

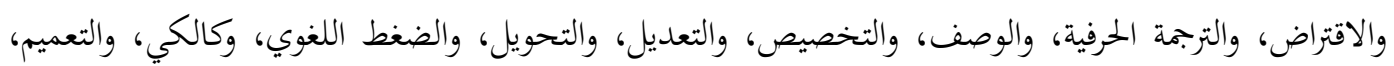

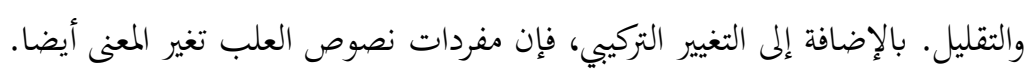

$$
\begin{aligned}
& \text { الكلمات المفتاحية: تقنية الترجمة، اللغة الإندونيسية، العربية، المنتجات. }
\end{aligned}
$$

\section{A. Pendahuluan}

Praktik penerjemahan sesungguhnya telah lama dilakukan oleh manusia sejak berabad-abad yang lalu. Kegiatan ini telah menjadi prioritas utama kemajuan suatu bangsa hingga menjadi kebutuhan. Kegiatan ini kian marak dan berkembang di berbagai bidang. Ini mengingat bahwa masih banyak teks-teks yang belum diterjemahkan ke dalam berbagai bahasa. Mengutip pernyataan Newmark (2003:55) dalam esainya yang menyebutkan, no global communication without translation, 'tidak ada komunikasi global tanpa penerjemahan'. Maksud dari komunikasi global tersebut ialah komunikasi lintas bahasa yang menjadi peran utama demi kemajuan peradaban. Dalam perkembangan zaman, ilmu pengetahuan dunia semakin pesat berkembang seiring berjalannya waktu. Pada saat itu pula, pelbagai penelitian dituangkan ke dalam bentuk buku-buku dengan bahasa yang beragam dari berbagai belahan bangsa di 
dunia.

Indonesia merupakan salah satu negara berkembang yang perlu memikirkan bagaimana memperoleh dan menyerap ilmu pengetahuan, teknologi, dan budaya yang literaturnya masih banyak ditulis dengan menggunakan bahasa asing. Pentingnya penerjemahan di Indonesia mulai dirasakan terutama sejak Konferensi Tingkat Tinggi (KTT) NonBlok ke 10 di Jakarta tahun 1992 (Machali, 2009:190). Saat itu dibutuhkan sekitar 5000 ahli kebahasaan termasuk penerjemah. Akan tetapi jumlah tersebut belum mencukupi, mengingat masih sedikitnya ahli bahasa dan penerjemah di Indonesia pada saat itu. Berdasarkan konteks tersebut, maka dapat dikatakan bahwa kegiatan penerjemahan memang memainkan peran yang penting karena kegiatan ini merupakan instrumen untuk mengkomunikasikan pesan secara tepat dan akurat ke berbagai bahasa. Kebijakan politik, dokumen hukum, dokumen penelitian, naskah keagamaan, serta karya sastra merupakan contoh teks yang sering kali mendapat perhatian khusus.

Pada dasarnya kegiatan penerjemahan merupakan upaya mencari padanan kata-kata yang terdapat dalam satu bahasa dengan kata-kata dalam bahasa lain. Selain seorang penerjemah harus mengenali bentuk dan sistem bahasa, unsur budaya pun harus ia kenali. Hal demikian dapat berpengaruh pada hasil terjemahannya. Senada dengan Geoffrey (2010:34) yang mengatakan bahwa bahasa mencerminkan budaya dan seorang penerjemah harus mampu memahami budaya tersebut serta langkah stereotip dalam mereproduksi makna teks sumber. Artinya, penerjemahan tidak hanya terpaku dengan padanan leksikal pada kamus saja, akan tetapi juga mampu memaknainya dari sisi teks dan konteks. Sebab keberterimaan hasil terjemahan dirasakan oleh pembaca. Dengan kata lain, pembaca hanya melihat 'hasil' dari praktik penerjemah, bukanlah 'praktik' penerjemahannya (Machali, 2009:30).

Topik penelitian yang akan diangkat dalam tulisan ini berkaitan dengan teknik penerjemahan kosakata pada kemasan produk. Dalam teori-teori penerjemahan, pembahasan tersebut menjadi poin penting untuk melakukan kegiatan pengalihan bahasa. Fokus kosakata yang menjadi bahasa sumber (selanjutnya BSu) adalah bahasa Indonesia dan yang menjadi bahasa sasaran (selanjutnya BSa) adalah bahasa Arab. Data teks yang diambil dalam penelitian ini yaitu teks kemasan produk. Hal ini menarik karena produk merupakan salah satu barang yang akrab dengan kehidupan sehari-hari. Produk yang dimaksudkan dalam pembahasan ini merupakan olahan makanan dalam negeri yang pada bungkus kemasannya tertera teks bahasa Indonesia sebagai $\mathrm{BSu}$ dan teks bahasa Arab sebagai BSa. Jika diamati, bahasa produk sedikit berbeda dengan bahasa buku. Bahasa produk lebih singkat, padat, jelas. Berbeda dengan bahasa buku yang lebih deskriptif dan terperinci. Teks berikut terdapat pada produk Richeese dan Richoco yang masih dalam satu perusahaan, yakni PT. Kaldu Sari Nabati Indonesia. Pada kemasan tersebut tertera teks,

(1) BSu: wafer krim cokelat

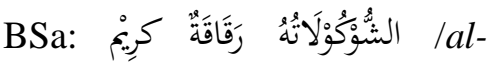

syukūlātah raqāqah krīm/

(2) BSu: wafer krim keju

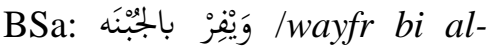
jubnahl

Apabila dianalisis kata demi kata, maka pada teks pertama, 'coklat' diterjemahkan al-syukūlātah, 'wafer' diterjemahkan raqāqah, dan 'krim' diterjemahkan krīm. Semua kosakata tersebut dipadankan ke dalam bahasa Arab secara harfiah. Lain halnya dengan teks kedua, 'wafer' diterjemahkan wayfr, dan 'krim keju' menjadi al-jubnah. Inilah salah satu penggunaan teknik penerjemahan. Apabila dianalisis keduanya memiliki teknik penerjemahan yang berbeda. Contoh tersebut merupakan teks yang sering kita temukan dalam kemasan sebuah produk makanan. Pengetahuan mengenai teknik penerjemahan merupakan salah satu teori yang harus dimiliki oleh seorang 
penerjemah. Tanpa pengetahuan ini, dapat dipastikan hasil terjemahan akan sulit untuk dipahami oleh pembaca BSa. Paling tidak penerjemah mampu memadankannya sedekat mungkin ke dalam BSa.

Penelitian mengenai analisis penggunaan teknik penerjemahan pada istilah-istilah teks kemasan produk masih jarang dilakukan, khususnya dari bahasa Indonesia ke dalam bahasa Arab. Seorang penerjemah tidak hanya dituntut untuk dapat menerjemahkan dari bahasa asing ke dalam bahasa ibu, tetapi juga dituntut untuk dapat menerjemahkan dari bahasa ibu ke dalam bahasa asing. Berdasarkan latar belakang di atas, makalah ini mengidentifikasi permasalahan teknik penerjemahan kosakata yang menjadi fokus penelitian. Rumusan masalah dapat ditulis sebagai berikut, bagaimana teknik yang digunakan penerjemah dalam memadankan kosakata pada kemasan makanan dari bahasa Indonesia ke dalam bahasa Arab berdasarkan teori Molina dan Albir?

\section{B. Kerangka Teoretis}

Berikut ini kerangka teori yang digunakan untuk membahas masalah pada makalah ini. Kerangka teori tersebut terdiri dari definisi penerjemahan dan teknik penerjemahan.

\section{Definisi Penerjemahan}

Istilah 'penerjemahan' dalam bahasa Indonesia berasal dari kata 'terjemah', dimana kata tersebut merupakan serapan dari bahasa Arab, yakni ترجمة/tarjamah/. Apabila dilihat dalam Kamus Besar Bahasa Indonesia (KBBI) disebutkan bahwa terjemah atau menerjemahkan berarti menyalin (memindahkan) suatu bahasa ke bahasa lain. Beberapa definisi berikut merupakan pandangan para tokoh di bidang kebahasaan dalam tulisannya tentang penerjemahan, di antaranya Catford (1965) mengatakan, translation is the replacement of textual material in one language $(S L)$ by equivalent textual material in another language (TL). 'Terjemah adalah penggantian materi tekstual dalam suatu bahasa (BSu) dengan materi tekstual yang sepadan dengan bahasa lain (BSa). Nida dan Taber (1974: 12) juga mengemukakan bahwa, penerjemahan adalah usaha mencipta kembali pesan dalam BSu ke dalam BSa dengan padanan alamiah yang sedekat mungkin, pertama dalam hal makna dan kemudian gaya bahasanya.' Menurut Catford yang harus sepadan ialah materi tekstualnya, ini bisa jadi kosakata, struktur gaya bahasa, dan makna. Demikian juga yang dikatakan Nida dan Taber yang menyinggung padanan makna dan gaya bahasa penerjemahan dalam definisinya.

$$
\text { Penjelasan lain yang juga }
$$

menyinggung tentang makna ialah Syihabuddin. Ia mendefinisikan penerjemahan sebagai pengungkapan makna tuturan suatu bahasa di dalam bahasa lain dengan memenuhi seluruh makna dan maksud tuturan itu. Tak jauh beda dengan Larson (1989: 3), dalam bukunya ia juga menulis bahwa penerjemahan pada dasarnya adalah suatu perubahan bentuk makna bahasa dari $\mathrm{BSu}$ ke dalam BSa. Bentuk bahasa yang dimaksud adalah struktur lahir bahasa yang mengacu pada kata, frasa, klausa, kalimat, paragraf, baik lisan maupun tertulis. Konsep penerjemahan yang diungkapkan oleh keempat tokoh tersebut ialah mengenai padanan makna dalam BSa. Makna yang muncul pada BSa merupakan hasil pemadanan sesuai dengan apa yang ada dalam BSu, ini bertujuan agar pembaca dapat memahami makna yang disampaikan penulis. Dengan kata lain, definisi ini menekankan bahwa meskipun gaya bahasa itu penting, tetapi makna yang disampaikan harus menjadi prioritas utama dalam penerjemahan.

Lain halnya pakar penerjemahan, Newmark (1981: 7) yang menjelaskan bahwa, translation is a craft consisting in the attempt to replace a written message and/or statement in one language by the same message and/or statement in another language. 'Penerjemahan adalah suatu kiat yang merupakan usaha untuk mengganti suatu pesan atau pernyataan tertulis dalam satu bahasa dengan pesan atau pernyataan yang sama dalam bahasa lain. Sementara Syarif Hidayatullah mendefinisikan 
terjemah sebagai proses memindahkan pesan yang diungkapkan BSu ke dalam BSa secara sepadan dan wajar sehingga tidak menimbulkan kesalahpersepsian (Hidayatullah, 2014: 17). Keduanya mengungkapkan bahwa kesepadanan pesan dari $\mathrm{BSu}$ ke dalam $\mathrm{BSa}$ harus diperhatikan.

Adapun proses penerjemahan, maksudnya adalah serangkaian kegiatan yang dilakukan oleh seorang penerjemah pada saat mengalihkan amanat dari BSu ke dalam BSa (Nababan, 2008: 24). Seorang penerjemah dituntut untuk mempelajari leksikon, struktur gramatikal, situasi komunikasi, dan konteks budaya dari teks BSu. Oleh karena itu, dalam melakukan penerjemahan diperlukan kehati-hatian agar tidak menimbulkan kesalahan yang menyebabkan ketidakberterimaan pesan yang disampaikan.

Berdasarkan beberapa definisi tersebut dapat disimpulkan bahwa penerjemahan berfokus pada padanan suatu bahasa dalam bahasa lain. Mungkin kata sepadan atau padanan tersebut lebih tepat digunakan dalam dunia penerjemahan mengingat secara linguistik tidak ada kata-kata yang sama (persamaan) dalam bahasa yang berlainan. Sehingga penerjemahan dapat didefinisikan sebagai bentuk kegiatan dalam upaya untuk menyampaikan kembali pesan yang terdapat dalam $\mathrm{BSu}$ dengan memperhatikan aspek kesepadanannya agar pesan dapat diterima dan dipahami oleh pembaca BSa.

\section{Teknik Penerjemahan}

Teknik penerjemahan adalah cara yang digunakan untuk mengalihkan pesan dari $\mathrm{BSu}$ ke BSa yang diterapkan pada tataran kata, frasa, klausa maupun kalimat. Penggunaan teknik-teknik dalam proses penerjemahan akan membantu penerjemah dalam menentukan bentuk dan struktur kata, frasa, klausa, serta kalimat terjemahannya. Teknik penerjemahan yang diusulkan Molina dan Albir (2002:509) memiliki 18 macam. Pada tulisan ini peneliti mengacu pada teoriteori tersebut. Berikut adalah penjabarannya.

a. Adaptasi (adaptation)

Merupakan teknik penggantian unsur budaya BSu dengan hal yang sifatnya sama pada budaya BSa. Teknik ini sama dengan teknik yang diungkapkan oleh ahli lainnya seperti cultural equivalent, cultural substitution, atau padanan budaya. Konsep adaptasi di atas juga selaras dengan pendapat Newmark (1988:91).

b. Amplifikasi (amplification)

Merupakan teknik penerjemahan yang mengeksplisitkan atau memparafrasa suatu informasi yang implisit dalam BSu. Amplifikasi merupakan lawan dari reduksi atau pengurangan. Hal senada juga diungkapkan oleh Newmark (1988:90) sebagai parafrase dalam prosedur penerjemahannya, Newmark mengungkapkankan bahwa parafrasa adalah penjelasan tambahan makna dari sebuah segmen teks karena segmen tersebut mengandung makna yang tersirat atau hilang, sehingga perlu dijelaskan atau diparafrasa sehingga menjadi lebih jelas.

c. Peminjaman (borrowing)

Merupakan teknik penerjemahan yang dilakukan oleh penerjemah dengan meminjam kata atau ungkapan BSu. Peminjaman itu bisa bersifat murni (pure borrowing) atau peminjaman yang sudah dinaturalisasi (naturalized borrowing).

d. Kalke (calque)

Merupakan teknik penerjemahan dengan mentransfer kata atau frasa dari BSu secara harfiah ke BSa baik secara leksikal maupun struktural. Interferensi struktur bahasa sumber pada bahasa sasaran adalah ciri khas dari teknik ini.

e. Kompensasi (compensation) Merupakan teknik penerjemahan dengan memperkenalkan elemen informasi atau efek stilistik lain pada tempat lain pada BSa karena tidak ditempatkan pada posisi yang 
sama seperti dalam BSu.

f. Deskripsi (description)

Merupakan teknik yang digunakan untuk mengganti suatu istilah dengan mendeskripsikan bentuk atau fungsinya. Hal ini berbeda dengan amplifikasi yang mengeksplisitkan informasi yang implisit. Teknik yang termasuk jenis ini antara lain padanan deskriptif dan padanan fungsional dalam Newmark (1988:83).

g. Kreasi diskursif (discursive creation)

Merupakan teknik penggunaan suatu padanan temporer di luar konteks atau tak terprediksikan. Dengan kata lain teknik penerjemahan ini berupaya untuk menentukan atau menciptakan sebuah padanan sementara yang benar-benar di luar konteks yang tak terprediksi.

h. Kesepadanan lazim (established equivalent)

Merupakan penggunaan istilah yang telah lazim digunakan baik dalam kamus atau dalam bahasa sasaran sebagai padanan dari BSu tersebut. Teknik ini juga dikenal dengan recognized translational/accepted standard translation (Newmark, 1988:89) atau terjemahan resmi (Suryawinata \& Hariyanto, 2003).

i. Generalisasi (generalization)

Merupakan teknik penggunaan istilah yang lebih umum atau netral dalam bahasa sasaran. Dengan kata lain, penggunaan kosakata pada bahasa sumber bersifat khusus, sedangkan kosakata pada bahasa sasarannya bersifat umum.

j. Amplifikasi linguistik (linguistic amplification)

Merupakan teknik penambahan elemen linguistik sehingga terjemahannya lebih panjang. Teknik ini biasanya digunakan dalam dubbing.

k. Kompresi linguistik (linguistic compression)

Teknik ini mensintesis elemen linguistik yang ada menjadi lebih sederhana karena sudah dapat dipahami (Molina \& Albir, 2002:509).

1. Terjemahan harfiah (literal translation)

Merupakan teknik penerjemahan suatu kata atau ungkapan dengan kata per kata. Bentuk BSa disesuaikan dengan susunan dan makna literal yang terkandung dalam BSu.

m. Modulasi (modulation)

Merupakan teknik penerjemahan yang dilakukan dengan mengubah sudut pandang, fokus atau kategori kognitif dalam kaitannya terhadap BSu. Perubahan tersebut bisa dalam bentuk struktural maupun leksikal. Hal senada tentang modulasi juga diungkapkan oleh Newmark (1988:88).

n. Partikularisasi (particularization)

Merupakan teknik penerjemahan dengan penggunaan istilah yang lebih spesifik dan konkrit dalam BSa. Teknik ini merupakan kebalikan dari teknik generalisasi. Artinya, teknik penerjemahan partikularisasi mencoba menerjemahkan satu istilah dengan cara mencari padanan istilahnya tersebut secara lebih spesifik atau khusus.

o. Reduksi (reduction)

Merupakan teknik penerjemahan dengan mengimplisitkan informasi karena komponen maknanya sudah termasuk dalam bahasa sasaran. Teknik ini mirip dengan teknik penghilangan (ommission atau deletion atau subtraction) atau implisitasi.

p. Subtitusi (substitution: linguistic, paralinguistic)

Merupakan teknik penggantian elemen-eleman linguistik dengan paralinguistik (intonation, gesture) dan sebaliknya.

q. Transposisi (transposition)

Teknik penerjemahan ini merujuk pada penggatian kategori gramatikal atau struktural. Teknik ini sama dengan teknik pergeseran kategori, 
struktur dan unit. Ungkapan yang sama tentang transposisi diungkapkan pula sebagai shifts atau transposition.

r. Variasi (variation)

Merupakan teknik penggantian unsur linguistik atau paralinguistik (intonasi, gestur) yang mempengaruhi aspek keragaman linguistik. Misalnya penggantian gaya, dialek sosial, dialek geografis. Teknik ini lazim diterapkan dalam menerjemahkan naskah drama.

\section{Metodologi Penelitian}

Metode yang digunakan pada penelitian ini adalah metode deskriptif melalui pendekatan kualitatif. Hasil penelitian serta analisis diuraikan dalam bentuk deskripsi sesuai kualitas hasil analisis. Artinya, bahwa data yang didapat dan dianalisis adalah hasil pengamatan penulis tanpa menilai salah atau benar data tersebut (Sudaryanto, 2015). Peneliti membaginya menjadi tiga tahap, yaitu tahap penyediaan data, tahap analisis data, dan tahap penyajian hasil analisis data.

\section{Metode Penyediaan Data}

Pada penelitian ini, data yang diteliti berupa teks kemasan produk makanan berbahasa Indonesia dan terjemahannya dalam bahasa Arab. Adapun tahapan pengungumpulan data pertama, studi pustaka, yaitu peneliti menelusuri penelitian-penelitian terdahulu yang berhubungan dengan topik ini. Setelah ditemukan beberapa penelitian terdahulu, kemudian merumuskan permasalahan yang menjadi arah tujuan penelitian ini dengan membandingkan penelitian-penelitian sebelumnya, dan memberikan penelitian yang lebih komprehensif.

Kedua, tahap penyediaan data, peneliti menggunakan metode simak dan catat sebagai teknik lanjutan. Fokus penelitian ini terbatas pada teks terjemahan kedua bahasa. Peneliti juga menyimak data-data dengan metode simak dan teknik dasar berupa teknik sadap bebas libat cakap. Data kemudian dicatat berdasarkan perumusan masalah. Kemudian dilanjutkan dengan penganalisaan data dengan menggunakan teori yang telah dipaparkan.

\section{Metode Analisis Data}

Metode analisis data yang digunakan adalah metode padan translasional. Metode ini digunakan karena berhubungan dengan dua bahasa. Tahapan dalam analisis data adalah sebagai berikut:

a. Melihat secara keseluruhan teks BSu dan BSa yang terdapat dalam kemasan produk.

b. Memasukkannya pada tabel.

c. Menentukan pergeseran-pergeseran kebahasaan yang terlihat dalam kedua bahasa tersebut.

d. Menganalisis bagian unit yang lebih kecil, yakni kata dan frasa.

e. Menyajikan hasil analisis secara deskriptif.

\section{Metode Penyajian Hasil}

Teknik penyajian data disajikan dengan cara deskriptif berdasarkan kerangka analisis dan rumusan masalah yang telah ditetapkan. Penyajian deskriptif dipaparkan melalui kata-kata biasa sehingga menghasilkan informasi yang detail dan lengkap. Tahapan penyajian analisis data ini merupakan tahapan terakhir dalam penelitian. Tahapan ini dilakukan setelah data selesai teranalisis. Penyajiannya dilakukan dengan teknik formal dan informal.

\section{Pembahasan}

Data-data berikut merupakan hasil temuan yang peneliti catat dari berbagai kemasan produk makanan yang terdapat bahasa Indonesia dan bahasa Arab. Peneliti mengelompokkannya ke dalam teknik penerjemahan sesuai dengan teori Molina dan Albir. 


\begin{tabular}{|c|c|c|}
\hline Biru berlian & 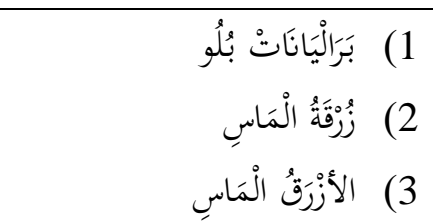 & $\begin{array}{l}\text { pungutan } \\
\text { harfiah } \\
\text { harfiah }\end{array}$ \\
\hline Kacang panggang & 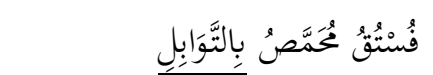 & amplifikasi \\
\hline Pengatur keasaman & 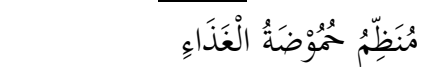 & amplifikasi \\
\hline Pengembang & عَامِلُ خَمِيْرَةٍ & deskripsi \\
\hline Berat bersih & الوَزْنُ الصَّافِيُّ & harfiah \\
\hline $\begin{array}{l}\text { Pengawet makanan } \\
\text { Natrium Benzoat }\end{array}$ & 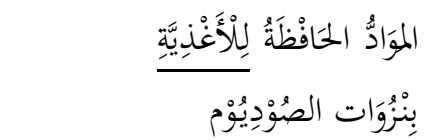 & $\begin{array}{l}\text { amplifikasi dan } \\
\text { kalke }\end{array}$ \\
\hline Vitamin C & فِيْتَامِيْن ج & pungutan \\
\hline Saus sambal & صَلْصَةُ الْفْلْفُلْ الحَارِ & deskripsi \\
\hline Rasa bawang pedas & فِلْفِلْ ـ ثُؤُمُ & partikularisasi \\
\hline Baik digunakan sebelum & 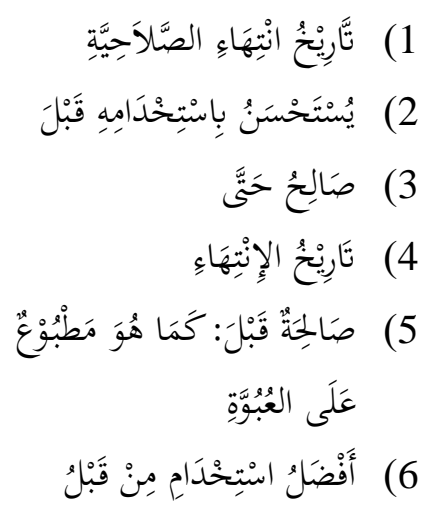 & $\begin{array}{l}\text { modulasi } \\
\text { transposisi } \\
\text { kompresi linguistik } \\
\text { modulasi } \\
\text { modulasi } \\
\text { transposisi }\end{array}$ \\
\hline Kode produksi & 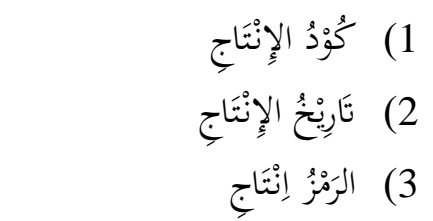 & $\begin{array}{l}\text { kalke } \\
\text { generalisasi } \\
\text { harfiah }\end{array}$ \\
\hline Diproduksi oleh & 1) & $\begin{array}{l}\text { amplifikasi } \\
\text { reduksi }\end{array}$ \\
\hline Jagalah kebersihan & حَافِظوُوا عََلَى نَظَََفَة & $\begin{array}{l}\text { transposisi dan } \\
\text { amplifikasi }\end{array}$ \\
\hline $\begin{array}{l}\text { Simpan di tempat } \\
\text { sejuk dan kering }\end{array}$ & 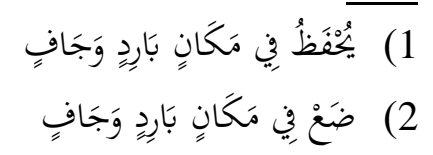 & $\begin{array}{l}\text { harfiah } \\
\text { harfiah }\end{array}$ \\
\hline$\frac{\text { Pewarna makanan }}{\text { merah allura CI } 16035}$ & 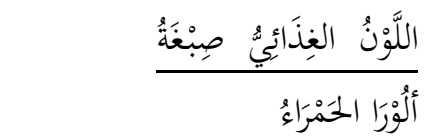 & $\begin{array}{l}\text { amplifikasi dan } \\
\text { kalke }\end{array}$ \\
\hline $\begin{array}{l}\text { Wafer krim cokelat } \\
\text { Pewarna tartrazin CI }\end{array}$ & الََلْوِيْنُ & $\begin{array}{l}\text { transposisi } \\
\text { amplifikasi dan }\end{array}$ \\
\hline
\end{tabular}




\begin{tabular}{|c|c|c|}
\hline 19140 & التَّارْتَازِيْنِ سي سي & pungutan \\
\hline & 19140 & \\
\hline $\begin{array}{l}\text { Perisa identik alami } \\
\text { cokelat }\end{array}$ & 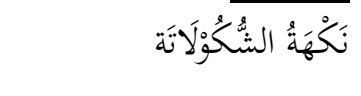 & reduksi \\
\hline $\begin{array}{l}\text { Pengatur keasaman } \\
\text { asam sitrat }\end{array}$ & سِيْتَ رَيْتِ اَسِيْت & partikularisasi \\
\hline Biskuit sandwich salut krim keju & بِنكُويْت سَانْدويْتش & reduksi \\
\hline & & \\
\hline Wafer krim keju & وَيْفِفْ بالجبُبنَه & reduksi \\
\hline Malkist & بسْكُويْتَ بالسُّكَّر & deskripsi \\
\hline $\begin{array}{l}\text { Makanan ringan rasa } \\
\text { ayam panggang }\end{array}$ & 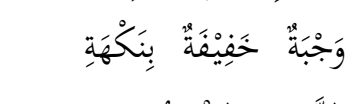 & amplifikasi \\
\hline Pewarna makanan sintesis & مُلّوّنُ اصْطنَاعٌٌُ & transposisi \\
\hline Kuning telur bubuk & صُفَارُ البَيْض & reduksi \\
\hline Bubuk bawang putih & 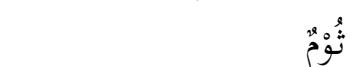 & reduksi \\
\hline Saran penyajian & تَعْلِيْمَاتُ الطَُّّخ & modulasi \\
\hline Kecap & كِيْجَاب & pungutan \\
\hline$\frac{\text { Keluarkan mi dari air dan }}{\text { tiriskan }}$ & 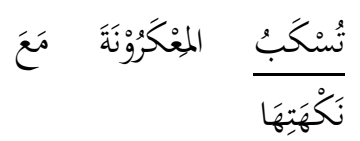 & modulasi \\
\hline Mi Sedaap siap untuk disajikan & 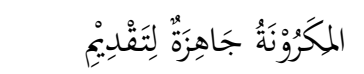 & reduksi \\
\hline Perisa identik alami rumput laut & 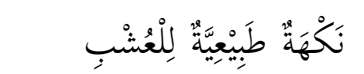 & reduksi \\
\hline & البَحْرِيٍّ & \\
\hline$\underline{\text { Rasa goreng spesial pedas }}$ & شَعِيْرِيَّةُ مَقْلِلَيَّة حَارِّ & modulasi \\
\hline Sirup glukosa & شَرَابُ الجُعْلُوكُوزَ & kalke \\
\hline Perisa artifisial blueberi & إصْطِنَاعِيُُّ نَكَهَهَة & transposisi \\
\hline
\end{tabular}

\section{Tabel 1. Data Temuan}

Pembahasan mengenai data dan teknik telah peneliti golongkan sesuai dengan hasil temuan pada sub pembahasan di bawah ini. Adapun untuk teknik-teknik yang tidak digunakan atau yang tidak ditemukan di dalam data, peneliti tidak mamasukkannya pada bagian pembahasan ini.

1. Amplifikasi

Teknik ini mengeksplisitkan atau memparafrasa suatu informasi yang implisit dalam BSu. Teknik ini merupakan lawan dari teknik reduksi. Penggunaannya dalam penerjemahan dilihat dengan adanya kosakata tambahan dalam teks Arabnya, baik berupa partikel ataupun kosakata baru sebagai penjelas. Akan tetapi kosakata penjelas tersebut hanyalah tambahan, dan bukan untuk mendeskripsikan. 


\begin{tabular}{|c|c|c|}
\hline Bahasa Indonesia (BSu) & Bahasa Arab (BSa) & $\begin{array}{l}\text { Bentuk } \\
\text { Penambahan }\end{array}$ \\
\hline Kacang panggang & فُسُتْتُقُ مُحَمَّصُ بِالتَّوَابِل & partikel + nomina \\
\hline Pengatur keasaman & 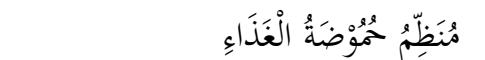 & nomina \\
\hline Pengawet makanan & 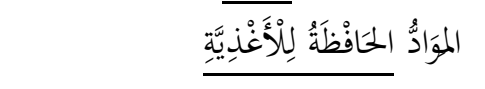 & $\begin{array}{l}\text { nomina }+ \text { partikel }+ \\
\text { nomina }\end{array}$ \\
\hline Diproduksi oleh & التَّتى تَنْتَجُجُهَا & partikel \\
\hline Jagalah kebersihan & & nomina \\
\hline Pewarna makanan & اللَّوَنُ الغِذَائيُيُّ صِبْغَةُ & nomina \\
\hline $\begin{array}{l}\text { Pewarna tartrazin CI } \\
19140\end{array}$ & تَلْوِيْنُ الطَُّعَام التَّرْتَازَيْنِ & nomina \\
\hline $\begin{array}{l}\text { Makanan ringan rasa } \\
\text { ayam panggang }\end{array}$ & 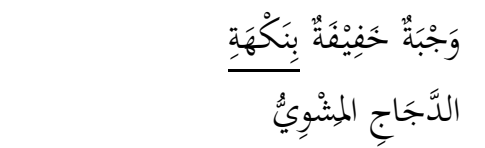 & partikel + nomina \\
\hline
\end{tabular}

Tabel 2. Data Teknik Amplifikasi

Beberapa partikel yang digunakan dalam amplifikasi ini di antaranya: dan التَّتى Sedangkan untuk kosakata tambahan berupa nomina di antaranya:

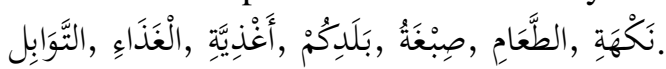
Kosakata-kosakata bahasa Arab tersebut tidak ditemukan dalam teks bahasa sumber, akan tetapi hanya sebagai penambahan informasi pada bahasa sasaran.

2. Pungutan

Teknik ini lebih banyak digunakan

\begin{tabular}{|c|c|c|}
\hline Bahasa Indonesia (BSu) & Bahasa Arab (BSa) & $\begin{array}{c}\text { Bentuk } \\
\text { Pungutan } \\
\end{array}$ \\
\hline Biru berlian & بَرَالْيَانَاتَ بُلُو & natural \\
\hline Vitamin C & فِيْتَامِيْن ج ج & murni \\
\hline $\begin{array}{l}\text { Pewarna tartrazin CI } \\
19140\end{array}$ & 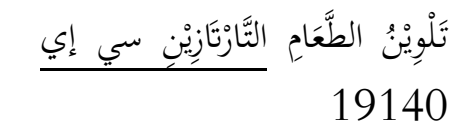 & natural \\
\hline Kecap & كِيْجَاب & natural \\
\hline
\end{tabular}

Tabel 3. Data Teknik Pungutan

Berdasarkan hasil temuan, terdapat dua macam bentuk peminjaman, yakni 
natural dan murni. Bentuk peminjaman natural lebih mendominasi dalam kasus ini. Hal tersebut diakibatkan pemungutan yang terjadi akibat adanya unsur fonologis yang agak berbeda antara kedua bahasa. Seperti pada 'kecap', dalam bahasa Arab tidak mengenal vokal 'e'. Maka, hasil terjemahannya menggunakan 'i' sebagai bentuk naturalisasinya, كَيْجَاب.

\section{Penerjemahan Harfiah}

Teknik penerjemahan ini dilakukan sesuai dengan makna literalnya pada kamus. Dalam temuan ini, semua susunan gramatikal pada kosakata BSa diterjemahkan seperti susunan BSu. Berikut adalah data yang peneliti temukan dalam teks kemasan produk makanan.

\begin{tabular}{|c|c|c|}
\hline Bahasa Indonesia (Bsu) & Bahasa Arab (Bsa) & $\begin{array}{l}\text { Bentuk } \\
\text { Harfiah }\end{array}$ \\
\hline Biru berlian & 1) الأْرَرَقُ الْمَاسِ & $\begin{array}{l}\text { frasa } \\
\text { frasa }\end{array}$ \\
\hline Berat bersih & الوَزْنُ الصَّاَفِيُُّ & frasa \\
\hline Kode produksi & الرَمْزُ إنتنَاجَ & frasa \\
\hline $\begin{array}{l}\text { Simpan di tempat } \\
\text { sejuk dan kering }\end{array}$ & 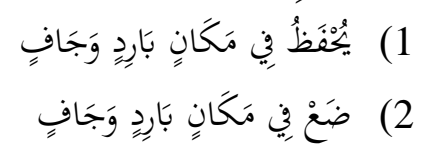 & $\begin{array}{l}\text { kalimat } \\
\text { kalimat }\end{array}$ \\
\hline
\end{tabular}

Tabel 4. Data Teknik Penerjemahan Harfiah

Hanya ditemukan dua bentuk struktur teks, yakni frasa dan kalimat. Agar lebih jelasnya, perhatikan susunan berikut.

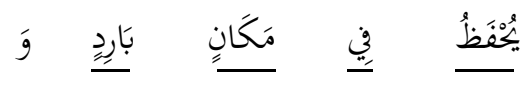

$$
\begin{aligned}
& \text { Kering dan sejuk tempat di } \\
& \text { simpan }
\end{aligned}
$$

Teknik ini mengganti istilah dengan mendeskripsikan kosakata BSu. Hal ini berbeda dengan amplifikasi yang mengeksplisitkan informasi yang implisit. Melalui pendeskripsian, pembaca $\mathrm{BSa}$ diharapkan dapat memahami pesan yang ingin disampaikan penerjemah terhadap kosakata tertentu yang sifatnya budaya atau perlu penjelasan lebih. Berikut adalah bentuk deskripsi yang diperoleh.

\begin{tabular}{|c|c|c|}
\hline Bahasa Indonesia (BSu) & Bahasa Arab (BSa) & Bentuk Pendeskripsian \\
\hline Pengembang & نامِلُ حَمَيْرِةٍ & frasa \\
\hline Saus sambal & مَلْصَةُ الْفُلْفُنْ الحَارِ & frasa kompleks \\
\hline Malkist & & klausa \\
\hline
\end{tabular}

4. Deskripsi

Tabel 5. Data Teknik Deskripsi

Kosakata BSu di atas diterjemahkan secara deskriptif dalam BSa. Pertama, pada kosakata 'pengembang' diterjemahkan menjadi 'proses peragian'. Kedua, 'sambal' diterjemahkan menjadi 'cabai pedas', bentuk tersebut dideskripsikan karena dalam masyarakat
Arab tidak mengenal istilah sambal seperti masyarakat Indonesia. Ketiga, 'malkist' yang dideskripsikan dengan 'biskuit dengan gula'.
5. Partikularisasi
Teknik ini merupakan kebalikan 
dari teknik generalisasi. Teknik penerjemahan partikularisasi mencoba menerjemahkan suatu istilah dengan cara mencari padanannya yang lebih spesifik atau khusus. Berdasarkan temuan, hanya terdapat dua data yang menggunakan teknik ini.

\begin{tabular}{|c|c|c|}
\hline Bahasa Indonesia (BSu) & Bahasa Arab (BSa) & Bentuk Partikularisasi \\
\hline Rasa bawang pedas & 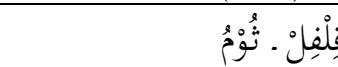 & kata \\
\hline Pengatur keasaman asam sitrat & بِيْتَ رَيْتِ اََِيْتَ & frasa \\
\hline
\end{tabular}

Tabel 6. Data Teknik Partikularisasi

Data pertama, pembaca BSu tentu memahami bahwa teks tersebut mengacu pada rasa makanan. Dalam terjemahannya, penerjemah hanya mengalihbahasakan sebagian dari teks BSu dengan tujuan supaya lebih spesifik, yakni berupa kosakata nomina saja. Data kedua, terdapat dalam komposisi makanan dengan memberikan padanan spesifik berupa bahan kimia yang digunakan.

\section{Modulasi}

Teknik ini berusaha untuk mengubah sudut pandang, fokus atau kategori kognitif pembaca BSa, baik dalam bentuk struktural maupun leksikal. Berikut adalah data yang diperoleh.

\begin{tabular}{|c|c|c|}
\hline Bahasa Indonesia (BSu) & Bahasa Arab (BSa) & $\begin{array}{c}\text { Teknik } \\
\text { Penerjemahan }\end{array}$ \\
\hline Baik digunakan sebelum & 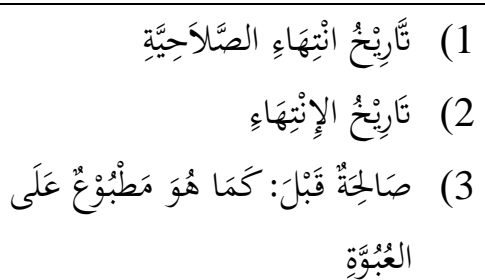 & $\begin{array}{l}\text { modulasi } \\
\text { modulasi } \\
\text { modulasi }\end{array}$ \\
\hline Saran penyajian & تَعْلِيمَاتُ الطُّبَّخ & modulasi \\
\hline $\begin{array}{l}\text { Keluarkan mi dari air dan } \\
\text { tiriskan } \\
\text { Rasa goreng spesial pedas }\end{array}$ & 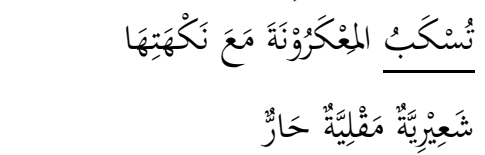 & $\begin{array}{l}\text { modulasi } \\
\text { modulasi }\end{array}$ \\
\hline
\end{tabular}

Tabel 7. Data Teknik Modulasi

Data pertama, bila diterjemahkan secara harfiah padanannya menjadi 'tanggal akhir yang sahih'. Dalam penerjemahan ini terdapat pergeseran makna bahasa Indonesia ke dalam bahasa Arab. Apabila diperhatikan bentuk BSa lebih konkret dengan mengacu pada istilah التَّارِنْخُ 'tanggal'. Berbeda dengan BSu yang masih bermakna abstrak. Begitu juga pada data kedua yang mengacu pada kosakata 'tanggal', maka dapat dipastikan bentuk ini juga merupakan modulasi. Data ketiga berusaha untuk memusatkan pembaca pada apa yang tertera di kemasan, yakni tanggal. Apabila dilihat dari BSu, kosakata diawali dengan kata sifat 'baik', ketiga terjemahannya mengacu pada 'tanggal'.

\section{Transposisi}

Pada teknik ini, penerjemah mengubah bentuk gramatikal $\mathrm{BSu}$ ke dalam teks BSa agar tercapai kesepadanan. Biasanya teknik ini ditempuh tatkala penerjemah tidak menemukan struktur BSa yang sama dengan struktur BSu. Pergeseran tersebut dapat berupa pengubahan bentuk jamak ke bentuk tunggal, bentuk tunggal menjadi jamak, verba jadi nomina, posisi kata sifat, 
hingga pengubahan struktur kalimat secara keseluruhan.

\begin{tabular}{|c|c|c|}
\hline Bahasa Indonesia (BSu) & Bahasa Arab (BSa) & $\begin{array}{c}\text { Bentuk } \\
\text { Transposisi }\end{array}$ \\
\hline Baik digunakan sebelum & 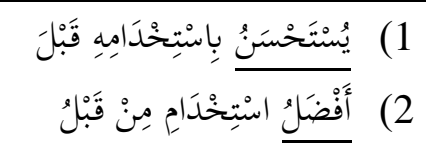 & $\begin{array}{l}\text { adverbia } \rightarrow \text { verba } \\
\text { adverbia } \rightarrow \text { superlatif }\end{array}$ \\
\hline Jagalah kebersihan & حَافِظْوا عَلَى نَظَافَفِة بَلَدِكُمْ & tunggal $\rightarrow$ jamak \\
\hline Wafer krim cokelat & 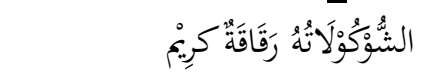 & perubahan susunan \\
\hline Pewarna makanan sintesis & مُلِّوِنْ اصْطِنَاعِيُّ لِلْمَأْكُوَلَاتِ & perubahan susunan \\
\hline Perisa artifisial blueberi & إصْطِنَاعِيُّ نَكْهَةَ تُوْتِ & perubahan susunan \\
\hline
\end{tabular}

Tabel 8. Data Teknik Transposisi

Secara harfiah, teks pertama pada poin 1 tersebut memiliki padanan 'sebaiknya menggunakannya sebelum'. Penerjemah menerjemahkan kata 'baik' dalam BSu menjadi يُسْتَحْسَنْ Sedangkan kata ini bentuk verba. Pada teks BSu kedua merupakan bentuk kalimat perintah sederhana yang diterjemahkan ke dalam

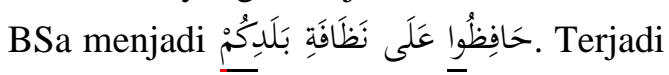
perubahan struktur bahasa Indonesia ke dalam bahasa Arab, yaitu dengan mengubah bentuk tunggal menjadi bentuk jamak yang ditandai dengan adanya حَافِظُو Garis bawa menandakan jamak yang mengacu pada pronomina kata ganti ketiga. Tandanya adalah Ig yang melekat pada kata kerja حَفِ Untuk teks BSu pada baris ke-3, 4, 5, pergesaran hanya terjadi pada perubahan susunannya saja. Seperti pada teks 'wafer krim coklat' yang pada terjemahannya didahului oleh

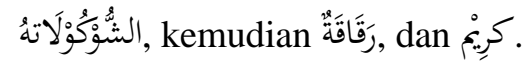

\section{Kompresi Linguistik}

Pada bentuk kompresi linguistik ini, terdapat kosakata yang dihilangkan sehingga dapat dilihat bentuk teks baru yang benar-benar singkat. Peneliti hanya mendapatkan 1 data teknik kompresi linguistik dalam teks kemasan. Berikut adalah data tersebut.

\begin{tabular}{lcc}
\hline \multicolumn{1}{c}{ Bahasa Indonesia (BSu) } & Bahasa Arab (BSa) & $\begin{array}{c}\text { Bentuk } \\
\text { Kompresi }\end{array}$ \\
\hline Baik digunakan sebelum & klausa -- frasa \\
\hline
\end{tabular}

Tabel 9. Data Teknik Kompresi Linguistik

Apabila diterjemahkan, teks BSa tersebut memiliki arti 'berlaku hingga'. Jika dibandingkan dengan teks BSu, dapat disimpulkan bahwa terjadi penyintesisan elemen linguistik.

9. Kalke
Teknik penerjemahan ini dilakukan dengan mentransfer kata atau frasa BSu secara harfiah ke BSa baik leksikal maupun struktural. Pada hasil temuan ini, unit penerjemahannya berupa frasa. Berikut ini adalah data temuannya.

\begin{tabular}{|c|c|c|}
\hline Bahasa Indonesia (BSu) & Bahasa Arab (BSa) & $\begin{array}{c}\text { Bentuk } \\
\text { Kalke } \\
\end{array}$ \\
\hline $\begin{array}{l}\text { Pengawet makanan } \\
\text { Natrium Benzoat }\end{array}$ & 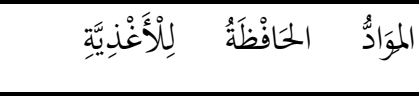 & Tidak mengikuti BSu \\
\hline
\end{tabular}


Kode produksi

Pewarna makanan merah allura CI

16035

Sirup glukosa

\section{بنْنْوَات الصُوْدِيُوْمِم}

كُوْدُ الإنْتَاج

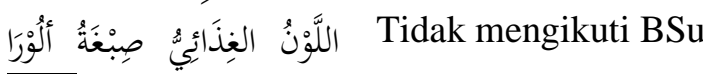

شَرَابُُ الجُلُْوكُوزَ

Tabel 10. Data Teknik Kalke

Terdapat dua macam bentuk, pertama, susunannya mengikuti struktur $\mathrm{BSu}$, 'kode produksi' dan 'sirup glukosa'. Kedua, susunannya tidak mengikuti struktur $\mathrm{BSu}$, 'natrium benzoat' dan 'merah allura'.
10. Generalisasi

Teknik ini digunakan dengan pemilihan istilah yang lebih umum pada BSa. Dengan kata lain, pada BSu bentuknya adalah khusus, sedangkan pada BSa bentuknya adalah umum. Data yang terhimpun hanya satu.

\section{Bahasa Indonesia (BSu)}

Bahasa Arab (BSa)

Bentuk

Generalisasi

Kode produksi

نَارِيْخُ الإنْتَاج kode -- tanggal

Tabel 11. Data Teknik Generalisasi

Penggunaan kosakata 'kode' sebenarnya memang merujuk pada tanggal dalam konsep pemikiran masyarakat Indonesia. Akan tetapi, penerjemah dalam kasus ini mengalihkannya menjadi lebih umum, yakni تَارِيْنُ /ta:ri:kh/ yang artinya adalah 'tanggal'.

11. Reduksi
Teknik ini adalah kebalikan dari amplifikasi, yakni dengan melakukan pemadatan informasi atau mengimplisitkan informasi pada hasil terjemahannya. Berikut merupakan data temuan.

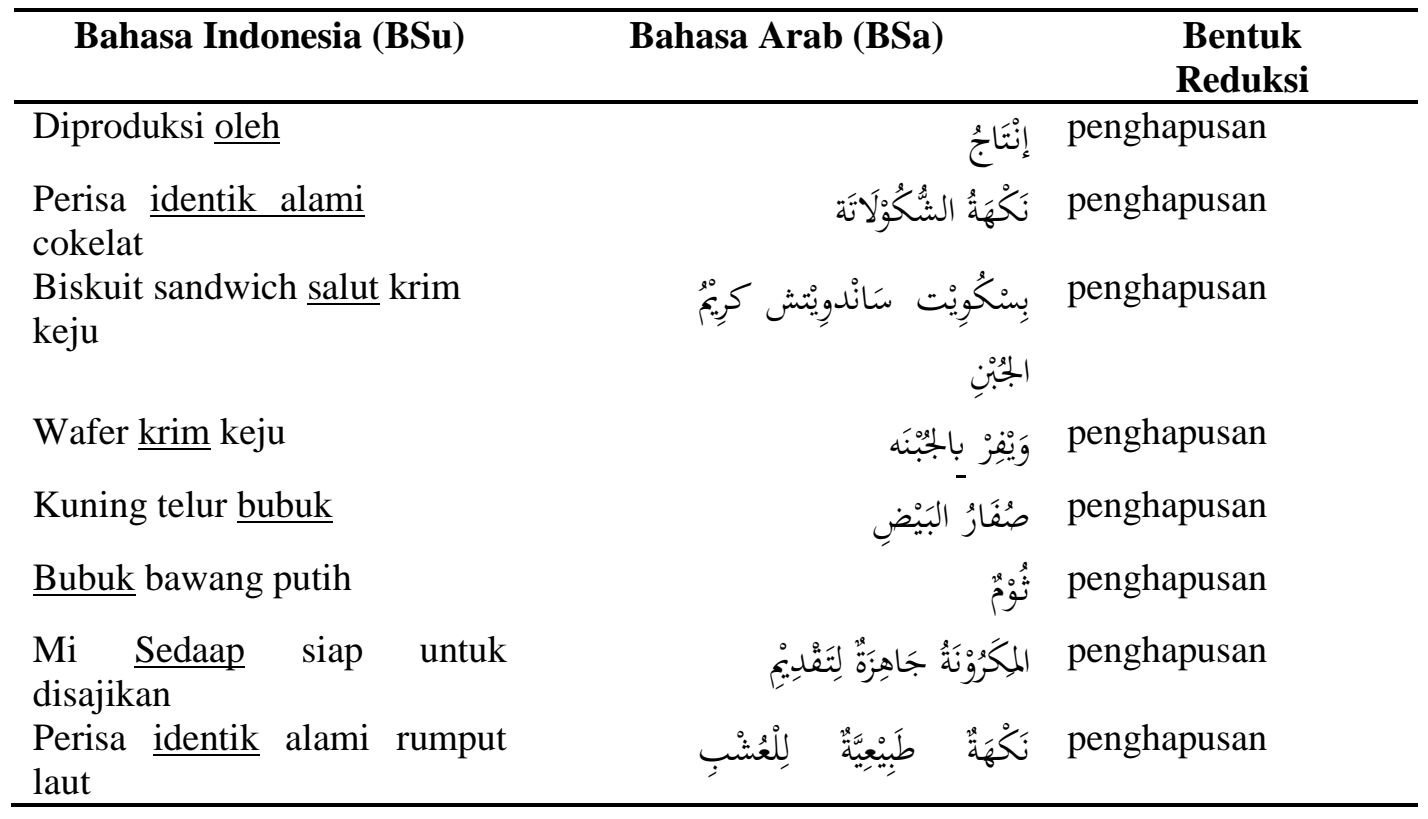




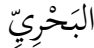

Tabel 12. Data Teknik Reduksi

Berdasarkan hasil temuan tersebut, peneliti menyimpulkan bahwa dalam kasus reduksi lebih menekankan pada penghapusan unsur kata yang kurang penting apabila diterjemahkan ke dalam BSa. Seperti nama produk 'Sedaap' yang tidak diterjemahkan, kosakata 'identik' yang mengacu pada artifisial atau bahan buatan untuk makanan. Selain itu ada pula kosakata 'salut', 'krim', 'bubuk' yang tidak diterjemahkan dalam teks BSa.

\section{E. Kesimpulan}

Berdasarkan temuan dan hasil analisis dapat disimpulkan terdapat 11 teknik penerjemahan yang dilakukan dalam mengalihkan teks kemasan makanan dari bahasa Indonesia ke dalam bahasa Arab. Kesebelas teknik tersebut antara lain amplifikasi, peminjaman, penerjemahan harfiah, deskripsi, partikularisasi, modulasi, transposisi, kompresi linguistik, kalke, generalisasi, dan reduksi. Penggunaan teknik-teknik tersebut bertujuan untuk memberikan kesepadanan antara kedua bahasa. Selain mengalami pergeseran bentuk/struktur, kosakata pada teks kemasan juga mengalami pergeseran makna dalam hasil terjemahannya. Pergeseran-pergeseran tersebut dapat dilihat dari beragam penggunaan teknik penerjemahannya. Untuk pergeseran struktur, teknik yang mendasarinya antara lain amplifikasi, transposisi, kompresi linguistik, kalke, dan reduksi. Sedangkan untuk kosakata yang mengalami pergeseran makna, teknik yang mendasarinya antara lain deskripsi, partikularisasi, modulasi, dan generalisasi. Adapun kosakata yang tidak merubah struktur maupun maknanya yaitu peminjaman dan penerjemahan harfiah.

\section{Daftar Referensi}

Catford, J. C. 1965. A Linguistic Theory of Translation: An Essay in Applied Linguistics. London: Oxford University Press.
Farizi, M. Zaka Al. 2011. Pedoman Penerjemahan Arab-Indonesia. Bandung: PT. Remaja Rosdakarya.

Hidayatullah, Moch. Syarif. 2014. Seluk Beluk Penerjemahan ArabIndonesia Kontemporer. Ciputat: Alkitabah.

Larson, Mildred L. 1989. Penerjemahan Berdasar Makna: Pedoman untuk Pemadanan Antarbahasa. Jakarta: Arcan.

Machali, Rochayah. 2009. Pedoman Bagi Penerjemah: Panduan Lengkap Bagi Anda yang Ingin Menjadi Penerjemah Profesional. Bandung: PT. Mizan Pustaka.

Nababan, Rudolf. 2008. Teori Menerjemah Bahasa Inggris. Yogyakarta: Pustaka Pelajar.

Newmark, Peter. 1981. Approaches to Translation (Language Teaching Methodology Series), Oxford: Pergamon Press. 1988. A Textbook of Translation, London: Prentice Hall International (UK) Ltd.

2003. No Global Communication Without Translation. Dalam Translation Today: Trends and Perspectives, penyunting oleh Gunilla Anderman dan Margaret Rogers, 55-67. Clevedon: Multilingual Matters Ltd.

Nida, Eugene A. dan Charles R. Taber. 1974. The Theory and Practice of Translation. Leiden: E. J. Brill.

Samuelsson-Brown, Geoffrey. 2010. A Practical Guide for Translators fifth revised edition. Great Britain: Short Run Press Ltd.

Sudaryanto. 2015. Metode dan Aneka Teknik Analisis Bahasa. Sanata Dharma University Press.

Suryawinata, dkk. 2003. Translation: 
Program Studi Sastra Arab FIB UNS Surakarta

Bahasan Teori \& Penuntun Praktis

Menerjemahkan. Yogyakarta:

Kanisius. 